\title{
Currently Used Pesticides in Water Matrices in Central-Western Brazil
}

\author{
Elisângela N. Nogueira, ${ }^{a}$ Eliana F. G. C. Dores, ${ }^{*}, a$ Alício A. Pinto, ${ }^{a}$ \\ Ricardo S. S. Amorim, ${ }^{b}$ Maria L. Ribeiro ${ }^{c}$ and Carolina Lourencetti, ${ }^{a}$ \\ ${ }^{a}$ Departamento de Química and ${ }^{b}$ Departamento de Solos e Engenharia Rural, \\ Universidade Federal de Mato Grosso, Campus de Cuiabá, 78060-900 Cuiabá-MT, Brazil
}

${ }^{c}$ Centro Universitário de Araraquara, 14801-340 Araraquara-SP, Brazil

\begin{abstract}
Este estudo fornece dados sobre a presença dos pesticidas atrazina, clorpirifós, $\alpha$-endossulfam, $\beta$-endossulfam, flutriafol, malatiom e metolacloro em água de áreas urbanas e rurais das cidades de Campo Verde e Lucas do Rio Verde, no estado do Mato Grosso, Brasil. Amostras de água superficial, de chuva e subterrânea foram coletadas nas estações de seca e chuva em 2007 e 2008 nessas importantes áreas produtoras de grãos. Os resultados revelaram maior diversidade de substâncias e frequência de detecção em amostras de água de chuva. Concentrações de atrazina, endossulfam e malatiom foram encontradas acima dos níveis permitidos pela legislação brasileira em algumas amostras de água superficial e subterrânea, e os metabólitos DIA (de-isopropil-atrazina) e endossulfam sulfato foram encontrados em níveis maiores do que os compostos parentais em algumas amostras. Nossos resultados demonstram a vulnerabilidade dos recursos hídricos nessas áreas e apontam para o risco de contaminação de áreas de nascentes de importantes córregos por pesticidas.
\end{abstract}

This study provides data on the presence of the pesticides atrazine, chlorpyrifos, $\alpha$-endosulfan, $\beta$-endosulfan, flutriafol, malathion and metolachlor in water matrices in urban and rural areas of Campo Verde and Lucas do Rio Verde Cities, Mato Grosso State, Brazil. Surface, rain, and groundwater samples were collected in the rainy and dry seasons during 2007 and 2008 in these important grain-producing areas. The findings revealed a higher diversity of compounds and frequency of detection in the rain water than in surface and groundwater samples. Concentrations of atrazine, endosulfan and malathion above those permitted by Brazilian regulations were found in some surface and groundwater samples, and the degradation products DIA (deisopropylatrazine) and endosulfan sulfate, rather than their parental compounds, were found at higher levels in some samples. Our findings show the vulnerability of water systems in these areas and point to the risk of pesticide contamination in important headwater streams.

Keywords: pesticide, surface water, rain water, ground water, bulk deposition

\section{Introduction}

Recent studies in Brazil have shown the presence of pesticides in water matrices, mainly in surface and ground water. However, considering the size of the country and the total amounts of pesticides applied, the number of studies describing pesticides in surface water ${ }^{1-20}$ and in ground water $^{16-25}$ is not large. Most of these studies have examined organochlorine pesticides, most of which have been

\footnotetext{
*e-mail: eliana@ufmt.br

"Current address: Instituto Federal de Educação, Ciência e Tecnologia de São Paulo, Campus Avançado de Matão, 15990-040 Matão-SP, Brazil
}

banned in Brazil since the 1980s, except for endosulfan, which will be prohibited beginning in $2013 .{ }^{26}$ The main reason for these results is attributed to the large amounts of pesticides employed in agriculture both in the past and recently to maintain high productivity of different crops such as soybeans, sugar cane, corn and cotton.

The pesticides when used in agriculture can reach different environmental matrices as they are lost from fields through volatilization, runoff, leaching and atmospheric deposition. ${ }^{27}$ Water resources are among the final destinations for these compounds.

Rain water is also not free of pesticides since substances volatilized into the atmosphere can return to the soil, 
plants and surface water through wet and dry deposition. ${ }^{28,29}$ Some studies have associated the presence of pesticides in rain water with those in ambient air, occurring not only in rural areas where pesticides are widely applied, but also in locations where pesticides have not been used, such as remote environments and urban areas..$^{30,31}$

The extensive use of these compounds is a matter of concern for governmental authorities and society at large. Recently, two monitoring programs to determine pesticides in food, mainly fruits and vegetable crops (rice and beans) are currently in place in Brazil, which aimed at evaluating compliance with national MRLs (maximum residue limits): the Program on Pesticide Residue Analysis in Food (PARA), coordinated by the Ministry of Health, through the National Sanitary Surveillance Agency (Agência Nacional de Vigilância Sanitária - ANVISA), and the National Residue and Contaminant Control Program (Plano Nacional de Controle de Resíduos e Contaminantes - PNCRC), coordinated by the Ministry of Agriculture, Livestock and Food Supplies (MAPA). Results of these two programs are presented elsewhere. ${ }^{32}$ However, humans become exposed not only through food, but also from drinking water, skin absorption and inhalation. ${ }^{33}$

Pesticide levels in drinking water in Brazil are regulated by the Ministry of Health (regulation 2914/2011), ${ }^{34}$ while the Federal Environmental Agency controls surface water (regulation 357/2005) ${ }^{35}$ and ground water (regulation 396/2008). ${ }^{36}$ However, only a limited number of compounds are regulated, and a systematic monitoring is not performed yet in the entire country.

The presence of pesticides in water and in sediment samples from Mato Grosso State has been reported in several studies, and attributed to the intensive use of these compounds in agriculture..$^{10,17,22,37}$ This is a concern since this state is rich in water resources and the headwaters of major rivers of three important hydrographic basins (Paraguay, Amazon and Araguaia) are located within the state. Another important aspect is human exposure as intensive farming such as grain production occurs in most municipalities in the state, and the urban areas are surrounded by the fields.

The objective of our study is to identify whether there is a pattern of pesticides in water matrices (surface, rain and ground water) from urban and rural areas of two agricultural centers of the Mato Grosso State, Campo Verde and Lucas do Rio Verde Cities. It was tested for atrazine and its metabolites deethylatrazine (DEA) and deisopropylatrazine (DIA), chlorpyrifos, $\alpha$ - and $\beta$-endosulfan and its metabolite endosulfan sulfate, flutriafol, malathion, metolachlor and methyl parathion.

\section{Experimental}

\section{Reagent and material}

High-purity standards (97.6-99.9\%) of the pesticides (atrazine, chlorpyrifos, $\alpha$ - and $\beta$-endosulfan, flutriafol, malathion, methyl parathion and metolachlor) and metabolites (DIA and DEA endosulfan sulfate) were purchased from Dr. Ehrenstorfer Gmbh (Augsburg, Germany) and Sigma-Aldrich Company Ldt. (United Kingdom). All the solvents used including acetone (PA, QUEMIS), ethyl acetate (Tedia, USA), n-hexane (Mallinckrodt Baker, USA), toluene (Mallinckrodt Ultiam $\mathrm{AR}^{\circledR}$, Paris, Kentucky, USA) and methanol (J.T. Baker, USA) were pesticide-residue analysis grade.

\section{Analytical method}

The multi-residue extraction method was based on a procedure described elsewhere. ${ }^{10}$ Briefly, SPE cartridges were made by packing glass tubes $(8 \mathrm{~mL})$ with $1000 \mathrm{mg}$ of Bakerbond $\mathrm{C}_{18}$ (J.T. Baker, Grossgerau, Germany). The cartridges were conditioned with $10 \mathrm{~mL}$ of methanol followed by $10 \mathrm{~mL}$ of water. An aliquot of $500 \mathrm{~mL}$ of dissolved water phase $(0.47 \mu \mathrm{m}$ glass fiber filter $), \mathrm{pH}$ previously adjusted to $6.5-7.5$, was transferred to the

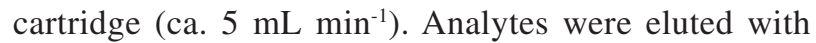
$10 \mathrm{~mL}$ portions of ethyl acetate and hexane:ethyl acetate (7:3) and a $5 \mathrm{~mL}$ portion of hexane. Different mixtures of solvent were required since the analytes presents not similar properties. Eluate was concentrated and the residue was redissolved in toluene $(1 \mathrm{~mL})$ with phenanthrene- $\mathrm{d}_{10}$ employed as internal standard. Method accuracy ranged from 73 to $127 \%$, and precision of the measurements was lower than $28 \%$, except for malathion, for which recovery ranged from 106 to $146 \%$. Limits of detection (LOD) and quantification (LOQ) ranged from 0.02 to

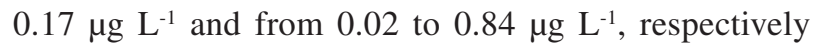
(Table 1). LOD and LOQ criteria are presented in the Supplementary Information (SI) section. Samples were analyzed in duplicate and procedural blanks were analyzed with each set of 20 samples analyzed.

\section{Analysis}

An HP 6890 series gas chromatograph coupled to an HP 5973 mass spectrometer (Hewlett-Packard GmbH, Germany), equipped with an HP 7683 autosampler, a split/ splitless injector and an HP-5MS (5\% phenylmethylsiloxane) column $(30 \mathrm{~m} \times 250 \mu \mathrm{m}$ id $\times 0.25 \mu \mathrm{m}$ phase thickness $)$ was used for pesticide identification and quantification. 
Table 1. Analytical data and limits of detection (LOD) and quantification (LOQ) for pesticide analysis by GC-MS

\begin{tabular}{|c|c|c|c|c|c|}
\hline Pesticide & Linear range $/\left(\mu \mathrm{g} \mathrm{mL}^{-1}\right)$ & $\mathrm{r}^{2}$ & SIM ions $^{\text {a }}$ & $\mathrm{LOD} /\left(\mu \mathrm{g} \mathrm{L}^{-1}\right)$ & $\mathrm{LOQ} /\left(\mu \mathrm{g} \mathrm{L}^{-1}\right)$ \\
\hline Atrazine & $0.20-21.24$ & 1.000 & $200.0,215.0,202.0$ & 0.03 & 0.20 \\
\hline DEA & $0.82-28.88$ & 1.000 & $172.0,187.0,174.0$ & 0.06 & 0.82 \\
\hline DIA & $0.84-36.94$ & 1.000 & $173.0,158.0,144.9$ & 0.17 & 0.84 \\
\hline Chlorpyrifos & $0.28-18.48$ & 0.999 & $196.9,198.9,313.9$ & 0.03 & 0.22 \\
\hline$\alpha$-Endosulfan & $0.22-17.44$ & 1.000 & $240.8,194.9,236.8$ & 0.06 & 0.22 \\
\hline$\beta$-Endosulfan & $0.10-14.46$ & 1.000 & $194.9,236.8,240.8$ & 0.03 & 0.10 \\
\hline Endosulfan sulfate & $0.22-24.42$ & 0.998 & $271.8,273.8,228.8$ & 0.08 & 0.22 \\
\hline Flutriafol & $0.20-20.58$ & 1.000 & $123.0,164.0,219.0$ & 0.06 & 0.20 \\
\hline Malathion & $0.20-28.50$ & 0.999 & $173.0,124.9,157.9$ & 0.03 & 0.20 \\
\hline Methyl parathion & $0.22-24.50$ & 0.999 & $262.9,108.9,124.9$ & 0.12 & 0.22 \\
\hline Metolachlor & $0.02-24.28$ & 0.999 & $162.1,238.0,146.0$ & 0.02 & 0.02 \\
\hline Phenanthrene ${ }^{b}$ & & & $188.1,189.0,184.0$ & & \\
\hline
\end{tabular}

a Ions used for substance quantification (first ion) and identification (second and third ions) during the selected ion monitoring (SIM); ${ }^{\text {internal standard; }}$ r: coefficient of correlation.

The column was set at $92{ }^{\circ} \mathrm{C}$ for $2.5 \mathrm{~min}$, ramped at $15^{\circ} \mathrm{C} \mathrm{min}^{-1}$ to $175^{\circ} \mathrm{C}$ (13 min hold time) and at $20^{\circ} \mathrm{C} \mathrm{min}^{-1}$ to $280{ }^{\circ} \mathrm{C}(9 \mathrm{~min})$. The injector $\left(250^{\circ} \mathrm{C}\right)$ was operated in splitless mode $(2.00 \mathrm{~min})$ with injection volume of $1 \mu \mathrm{L}$. Helium $(99,999 \%)$ was used as carrier gas at $1 \mathrm{~mL} \mathrm{~min}^{-1}$. Transfer-line was set at $290^{\circ} \mathrm{C}$. The mass spectrometer was operated in electron impact ionization mode (EI) at $70 \mathrm{eV}$. Standards and samples were injected in the time-scheduled selected ion monitoring mode (SIM) using three ions for each compound (Table 1). Maximum tolerance for confirmation was specified as $20 \%$ of relative ion intensity response.

\section{Study area}

Campo Verde (CV) and Lucas do Rio Verde (LRV) Cities, distant $130 \mathrm{~km}$ and $350 \mathrm{~km}$ from the capital Cuiabá, respectively, are two important agricultural centers of Mato Grosso State, Central-Western Brazil, with populations of approximately 30,760 and 45,130, respectively. These areas have a rainy season from November to April and a dry season from May to October. Total precipitation was $1750 \mathrm{~mm}$ and $2000 \mathrm{~mm}$ in CV and LRV, respectively, during the study period (Figure 1).

Agriculture in these areas is dominated by intensive soybean, cotton and corn cultivation. Information about the pesticides studied here, including their chemical and physical properties, classification, use in crops and amounts of pesticides sold in LRV and CV during 2007 and 2008 is presented in Table 2 and Table 3.

The locations of the sampling points in urban (UA), rural (RA) and surburban (P) areas are presented in Table 4.



Figure 1. Mean precipitation in Campo Verde and Lucas do Rio Verde.

Total sampling sites for surface water (SW), ground water (GW) and rain water (RW) were three, seven and four, respectively in $\mathrm{CV}$, and eight, ten and four, respectively in LRV. Depths of the wells ranged from 5 to $100 \mathrm{~m}$ in rural areas, and from 30 to $140 \mathrm{~m}$ in urban areas. In Campo Verde, surface-water samples were taken from the Casca River (SW52), São Lourenço River headwaters (SW57) and Lajes Stream. In Lucas do Rio Verde, samples were taken from the Lucas River (SW1 and SW2), Verde River (SW3, SW4, SW5 and SW6), Itambiquara River (SW12) and Cedro River (SW18).

\section{Sample collection and treatment}

In total, 96 water samples were collected from different water sources in the $\mathrm{CV}$ region, and 129 in the LRV region. The water samples were collected from October 2007 to May 2008, a period corresponding to an annual hydrological cycle, with sampling in both the dry and rainy seasons.

Water samples were collected in $1 \mathrm{~L}$ glass bottles, carefully filled to the brim to avoid trapping air in the 
Table 2. Chemical and physical properties of pesticides in the study area

\begin{tabular}{|c|c|c|c|c|c|c|c|c|}
\hline Pesticide & Use & Crop & Formula & $\begin{array}{c}\mathrm{P}_{\text {vap }} / \mathrm{mPa} \\
\left(25^{\circ} \mathrm{C}\right)\end{array}$ & $\begin{array}{c}\mathrm{K}_{\mathrm{H}}^{\mathrm{b}} / \\
\left(\mathrm{Pa} \mathrm{m}^{3} \mathrm{~mol}^{-1}\right) \\
\left(25^{\circ} \mathrm{C}\right)\end{array}$ & $\begin{array}{c}\mathrm{K}_{\mathrm{OC}}{ }^{\mathrm{c}} / \\
\left(\mathrm{mL} \mathrm{g}^{-1}\right)\end{array}$ & $\begin{array}{l}\mathrm{t}_{1 / 2}^{\mathrm{d}} / \\
\text { day }\end{array}$ & $\begin{array}{c}\mathrm{S}_{\mathrm{W}}{ }^{\mathrm{e}} / \\
\left(\mathrm{mg} \mathrm{L}^{-1}\right) \\
\left(20^{\circ} \mathrm{C}\right) \\
\end{array}$ \\
\hline Atrazine & $\mathrm{H}$ & corn, bean, cotton & $\mathrm{C}_{8} \mathrm{H}_{14} \mathrm{CN}_{5}$ & 0.039 & $1.50 \times 10^{-4}$ & 100 & 75 & 35 \\
\hline DEA & - & - & $\mathrm{C}_{6} \mathrm{H}_{10} \mathrm{ClN}_{5}$ & 12.4 & $1.55 \times 10^{-4}$ & 72 & 45 & 3200 \\
\hline DIA & - & - & $\mathrm{C}_{5} \mathrm{H}_{8} \mathrm{ClN}_{5}$ & & $1.52 \times 10^{-5}$ & 142 & - & 670 \\
\hline Chlorpyrifos & I & cotton, corn soybean, & $\mathrm{C}_{9} \mathrm{H}_{11} \mathrm{Cl}_{3} \mathrm{NO}_{3} \mathrm{PS}$ & 1.43 & $4.78 \times 10^{-1}$ & 8151 & 50 & 1.05 \\
\hline$\alpha$-Endosulfan & I & soybean, cotton, corn & $\mathrm{C}_{9} \mathrm{H}_{6} \mathrm{Cl}_{6} \mathrm{O}_{3} \mathrm{~S}$ & 0.83 & 1.48 & 11500 & 50 & 0.32 \\
\hline$\beta$-Endosulfan & I & soybean, cotton, corn & $\mathrm{C}_{9} \mathrm{H}_{6} \mathrm{Cl}_{6} \mathrm{O}_{3} \mathrm{~S}$ & 0.83 & 1.48 & 11500 & 50 & 0.32 \\
\hline Endosulfan sulfate & - & - & $\mathrm{C}_{9} \mathrm{H}_{6} \mathrm{Cl}_{6} \mathrm{O}_{3} \mathrm{~S}$ & 0.83 & 1.48 & 5194 & - & 0.48 \\
\hline Flutriafol & $\mathrm{F}$ & cotton, soybean & $\mathrm{C}_{16} \mathrm{H}_{13} \mathrm{~F}_{2} \mathrm{~N}_{3} \mathrm{O}$ & 0.44 & $1.27 \times 10^{-6}$ & 205 & 1358 & 95 \\
\hline Malathion & I & soybean, bean, cotton & $\mathrm{C}_{10} \mathrm{H}_{19} \mathrm{O}_{6} \mathrm{PS}_{2}$ & 3.1 & $1.00 \times 10^{-3}$ & 217 & 0.17 & 148 \\
\hline Methyl parathion & I & soybean, cotton, corn & $\mathrm{C}_{8} \mathrm{H}_{10} \mathrm{NO}_{5} \mathrm{PS}$ & 2.0 & $8.57 \times 10^{-3}$ & 240 & 12 & 55 \\
\hline Metolachlor & $\mathrm{H}$ & corn, soybean & $\mathrm{C}_{15} \mathrm{H}_{22} \mathrm{ClNO}_{2}$ & 1.7 & $2.40 \times 10^{-3}$ & 200 & 90 & 530 \\
\hline
\end{tabular}

${ }^{\mathrm{a}} \mathrm{P}_{\text {vap }}$ : vapor pressure; ${ }^{\mathrm{b}} \mathrm{K}_{\mathrm{H}}$ : Henry's Law constant; ${ }^{\mathrm{c}} \mathrm{K}_{\mathrm{OC}}$ : soil organic carbon sorption coefficient; ${ }^{\mathrm{d}} \mathrm{t}_{1 / 2}$ : half-live; ${ }^{\mathrm{e}} \mathrm{S}_{\mathrm{w}}$ : water solubility; I: insecticide; H: herbicide; F: fungicide; -: metabolite; Pesticide Properties Database (PPDB). ${ }^{38}$

Table 3. Application of pesticides in the study area in 2007 and 2008

\begin{tabular}{|c|c|c|c|c|}
\hline \multirow{3}{*}{ Pesticide } & \multicolumn{4}{|c|}{ Application ${ }^{\mathrm{a}} / \mathrm{kg}$} \\
\hline & \multicolumn{2}{|c|}{ Campo Verde } & \multicolumn{2}{|c|}{ Lucas do Rio Verde } \\
\hline & 2007 & 2008 & 2007 & 2008 \\
\hline Atrazine & 3926.3 & 3747.5 & 16547.3 & 73806.0 \\
\hline Chlorpyrifos & 22.4 & 3318.2 & 48.2 & 31.1 \\
\hline$\alpha$-Endosulfan & 67.0 & 91.0 & 30.5 & 63.6 \\
\hline$\beta$-Endosulfan & 32.2 & 43.8 & 14.7 & 30.6 \\
\hline Flutriafol & 0.7 & 7.0 & 0.2 & 0.2 \\
\hline Malathion & 43.8 & 42.6 & 7.9 & 39.4 \\
\hline Methyl parathion & 93.7 & 110.5 & 54.8 & 73.1 \\
\hline Metolachlor & 84170.0 & 93112.1 & 7449.6 & 47212.8 \\
\hline
\end{tabular}

${ }^{\mathrm{a}}$ Mato Grosso Institute for Agropecuary Defense (INDEA-MT, Brazil).

sealed containers. Rain water collectors consisted of a $4 \mathrm{~L}$ glass bottle connected to a stainless steel funnel $(30 \mathrm{~cm}$ diameter). Due to the sampling design, the bulk deposition of pesticides was measured, consisting of wet and dry deposition..$^{10}$ Sampling was carried out every two months for surface and ground water, and rain water samples were collected after each rain event. When a rain water sample volume was not available for analysis, samples collected subsequently from the closest rain event in the same sampling site were combined and analyzed together.

After filling, the bottles were sealed with Teflonlined screw caps, kept on ice in insulated containers and transported to the laboratory after $48 \mathrm{~h}$ maximum, where they were stored at $4{ }^{\circ} \mathrm{C}$ until extraction, which did not exceed 15 days. Because the distance between the study areas to the laboratory, rain water samples were stored at $4{ }^{\circ} \mathrm{C}$ after the rain events and transported to the laboratory once per month.

\section{Data treatment}

The data are presented by descriptive statistics: minimum, maximum, mean, median and frequency of detection. Wet deposition fluxes of individual pesticides $\left(\mathrm{mg} \mathrm{m}^{-2}\right)$ were calculated for each pesticide in each month, multiplying the concentration of pesticides in the samples for a given whole month (sum of concentrations of different samples collected in the month) $\left(\mu \mathrm{g} \mathrm{L}^{-1}\right)$ by the amount of rainfall in each month (Figure 1).

\section{Results and Discussion}

\section{Occurrence of pesticides in surface and ground water}

Nine of the eleven analytes were found in surfacewater and groundwater samples from CV and LRV, as summarized in Table 5. Figure 2 presents chromatograms of a standard solution (a) and of an example of a real sample (e), with the mass spectrum of the identified analytes atrazine, $\beta$-endosulfan and flutriafol in the solution $(b, c$ and d) and in the real samples (f, $g$ and $h$ ). Mean concentration distributions of pesticides among samples were strongly biased toward low values, considering the wide range of concentration and the low frequency of detection. Samples collected from rural and urban areas in CV and LRV did not differ significantly $(p<0.05)$.

Pesticides were detected with higher frequency in surface and groundwater samples from LRV than from CV. Higher values were observed for metolachlor and flutriafol (31\%) followed by endosulfan sulfate (29\%) in surface water and $\beta$-endosulfan (22\%) and $\alpha$-endosulfan (18\%) in ground water. Although the amounts of pesticides applied 
Table 4. Description of the sampling sites

\begin{tabular}{|c|c|c|c|}
\hline & Site & Location & Description \\
\hline \multirow{11}{*}{$\begin{array}{l}\text { Campo } \\
\text { Verde }\end{array}$} & SW52 & $15^{\circ} 36^{\prime} 58,3^{\prime} " \mathrm{~S} 55^{\circ} 24^{\prime} 23,6^{\prime \prime} \mathrm{W}$ & distant $27 \mathrm{~km}$ from the city and surrounded by agriculture \\
\hline & SW57 & $15^{\circ} 36^{\prime} 56,2^{\prime \prime} \mathrm{S} 55^{\circ} 24^{\prime} 22,2^{\prime \prime} \mathrm{W}$ & distant $8 \mathrm{~km}$ from the city and surrounded by agriculture \\
\hline & SW58 & $15^{\circ} 30^{\prime} 02,1^{\prime} \mathrm{S} 55^{\circ} 06^{\prime} 42,8^{\prime \prime} \mathrm{W}$ & distant $8 \mathrm{~km}$ from the city and surrounded by agriculture \\
\hline & RA-GW1 & $15^{\circ} 34^{\prime} 50,1^{\prime} " \mathrm{~S} \mathrm{55^{ \circ } 2 2}$ '19,3”W & located in the rural area, $100 \mathrm{~m}$ deep \\
\hline & RA-GW2, RA-RW2 & $15^{\circ} 34^{\prime} 41,99^{\prime} \mathrm{S} 55^{\circ} 21^{\prime} 46,2{ }^{\prime \prime} \mathrm{W}$ & located in the rural area, $100 \mathrm{~m}$ deep \\
\hline & P-GW1 & $15^{\circ} 32^{\prime} 45,68^{\prime \prime} \mathrm{S} 55^{\circ} 10^{\prime} 37,68^{\prime \prime} \mathrm{W}$ & located in the suburban area, n.i. \\
\hline & UA-GW1 & $15^{\circ} 32^{\prime} 36,9 ” \mathrm{~S} 55^{\circ} 10^{\prime} 10,6^{\prime \prime} \mathrm{W}$ & located in the urban area, $30 \mathrm{~m}$ deep \\
\hline & P-GW2, P-RW3 & $15^{\circ} 33^{\prime} 41,90^{\prime \prime} \mathrm{S} 55^{\circ} 10^{\prime} 24,0^{\prime \prime} \mathrm{W}$ & located in the suburban area, n.i. \\
\hline & RA-GW3 & $15^{\circ} 31^{\prime} 47,6^{\prime} \mathrm{S} 55^{\circ} 08^{\prime} 18,0^{\prime \prime} \mathrm{W}$ & located in the rural area, $40 \mathrm{~m}$ deep \\
\hline & RA-GW4, RA-RW4 & $15^{\circ} 36 ’ 54,1 ” S 55^{\circ} 11 ’ 18,0 ” \mathrm{~W}$ & located in the rural area, $5 \mathrm{~m}$ deep \\
\hline & UA-RW2 & $15^{\circ} 32 ’ 53,03^{\prime \prime} \mathrm{S} 55^{\circ} 10^{\prime} 23,0^{\prime \prime} \mathrm{W}$ & located in the urban area \\
\hline \multirow{18}{*}{$\begin{array}{l}\text { Lucas do } \\
\text { Rio Verde }\end{array}$} & SW1 & $13^{\circ} 05^{\prime} 51,8^{\prime \prime} \mathrm{S} 55^{\circ} 56^{\prime} 50,4^{\prime \prime} \mathrm{W}$ & distant $5 \mathrm{~km}$ from the city and surrounded by agriculture \\
\hline & SW2 & $13^{\circ} 03^{\prime} 36,3^{\prime \prime} \mathrm{S} 55^{\circ} 54^{\prime} 21,3^{\prime \prime} \mathrm{W}$ & distant $2 \mathrm{~km}$ from the city and nearby agriculture \\
\hline & SW3 & $13^{\circ} 06^{\prime} 06,8^{\prime \prime} \mathrm{S} 55^{\circ} 53^{\prime} 26,4^{\prime \prime} \mathrm{W}$ & distant $5 \mathrm{~km}$ from the city and surrounded by agriculture \\
\hline & SW4 & $13^{\circ} 03^{\prime} 09,0^{\prime \prime} \mathrm{S} 55^{\circ} 54^{\prime} 22,6^{\prime \prime} \mathrm{W}$ & distant $2 \mathrm{~km}$ from the city and nearby agriculture \\
\hline & SW5 & $13^{\circ} 02^{\prime} 52,6^{\prime \prime} \mathrm{S} 55^{\circ} 54^{\prime} 33,6^{\prime \prime} \mathrm{W}$ & distant $2 \mathrm{~km}$ from the city and nearby agriculture \\
\hline & SW6 & $12^{\circ} 52^{\prime} 16,3^{\prime \prime} \mathrm{S} 55^{\circ} 59^{\prime} 58,2^{\prime \prime} \mathrm{W}$ & distant $23 \mathrm{~km}$ from the city and surrounded by agriculture \\
\hline & SW12 & $12^{\circ} 48^{\prime} 55,6^{\prime \prime} \mathrm{S} 56^{\circ} 04^{\prime} 01,1^{\prime \prime} \mathrm{W}$ & distant $32 \mathrm{~km}$ from the city and surrounded by agriculture \\
\hline & SW18 & $13^{\circ} 17^{\prime} 32,9^{\prime \prime} \mathrm{S} 56^{\circ} 02^{\prime} 37,8^{\prime \prime} \mathrm{W}$ & distant $29 \mathrm{~km}$ from the city and surrounded by agriculture \\
\hline & UA-GW1, RA-RW1 & $13^{\circ} 04^{\prime} 29,4^{\prime \prime} \mathrm{S} 55^{\circ} 54^{\prime} 10,8^{\prime \prime} \mathrm{W}$ & located in the urban area, n.i. \\
\hline & UA-GW2 & $13^{\circ} 04^{\prime} 56,0^{\prime \prime} \mathrm{S} 55^{\circ} 54^{\prime} 37,3^{\prime \prime} \mathrm{W}$ & located in the urban area, $40 \mathrm{~m}$ deep \\
\hline & PA-GW1 & $13^{\circ} 04^{\prime} 18,0^{\prime \prime} \mathrm{S} 55^{\circ} 56^{\prime} 39,0^{\prime \prime} \mathrm{W}$ & located in the suburban area, $35 \mathrm{~m}$ deep \\
\hline & UA-GW3 & $13^{\circ} 04^{\prime} 13,8^{\prime \prime} \mathrm{S} 55^{\circ} 56^{\prime} 01,7^{\prime} \mathrm{W}$ & located in the urban area, $40 \mathrm{~m}$ deep \\
\hline & UA-GW4 & $13^{\circ} 04^{\prime} 02,9^{\prime \prime} \mathrm{S} 55^{\circ} 55^{\prime} 03,9^{\prime \prime} \mathrm{W}$ & located in the urban area, $120 \mathrm{~m}$ deep \\
\hline & RA-GW1 & $12^{\circ} 48^{\prime} 07,7^{\prime \prime} \mathrm{S} 56^{\circ} 03^{\prime} 44,5 \mathrm{~W}$ & located in the rural area, $35 \mathrm{~m}$ deep \\
\hline & RA-GW2, RA-RW2 & $12^{\circ} 46^{\prime} 44,8^{\prime \prime} \mathrm{S} 56^{\circ} 03^{\prime} 53,8^{\prime \prime} \mathrm{W}$ & located in the rural area, $30 \mathrm{~m}$ deep \\
\hline & RA-GW3, RA-RW3 & $12^{\circ} 59^{\prime} 48,4^{\prime \prime} \mathrm{S} 55^{\circ} 57^{\prime} 48,9^{\prime \prime} \mathrm{W}$ & located in the rural area, n.i. \\
\hline & RA-GW4, RA-RW4 & $13^{\circ} 18^{\prime} 26,5^{\prime \prime} \mathrm{S} 56^{\circ} 02^{\prime} 23,5^{\prime \prime} \mathrm{W}$ & located in the rural area, n.i. \\
\hline & RA-GW5 & $13^{\circ} 18^{\prime} 29,8^{\prime \prime S} 56^{\circ} 02^{\prime} 23,4 \mathrm{~W}$ & located in the rural area, n.i. \\
\hline
\end{tabular}

n.i.: not informed; RA: rural area; UA: urban area; P: suburban area; SW: surface water; GW: groundwater; RW: rainwater.

differed among compounds and years, it was not known if the rain events had occurred immediately following pesticide applications in these areas.

Atrazine, DEA, $\alpha$-endosulfan and $\beta$-endosulfan were found in surface-water samples collected in both CV and LRV. Malathion, metolachlor, chlorpyrifos, flutriafol and endosulfan sulfate were found only in surface-water samples from LRV.

Higher levels of atrazine and endosulfan, exceeding the guidelines for surface water established by the Brazilian Federal Environmental Agency (Instituto Brasileiro do Meio Ambiente e dos Recursos Naturais Renováveis -
IBAMA; $2 \mu \mathrm{g} \mathrm{L}^{-1}$ for atrazine and $0.056 \mu \mathrm{g} \mathrm{L}^{-1}$ for the total of $\alpha$-endosulfan, $\beta$-endosulfan and endosulfan sulfate $)^{35}$ were observed in LRV and CV. Excessive levels were found for atrazine during sampling in March and April at sites in CV (SW57) and LRV (SW18), respectively. Endosulfan exceeded the guideline levels in all the samples from LRV, where the isomers and degradation product were found. At least one sample from each sampling site exceeded the guideline levels for these compounds. Malathion also exceeded the guidelines for surface water, established as $0.1 \mu \mathrm{g} \mathrm{L}^{-1}, 35$ at sampling site SW2 in LRV in October 2008. 
Table 5. Pesticides in surface- and groundwater samples from Campo Verde and Lucas do Rio Verde

\begin{tabular}{|c|c|c|c|c|c|c|c|c|c|c|c|}
\hline & Matrix & & Atrazine & DEA & Chlorpyrifos & $\alpha$-Endosulfan & $\beta$-Endosulfan & $\begin{array}{c}\text { Endosulfan } \\
\text { sulfate }\end{array}$ & Flutriafol & Malathion & Metolachlor \\
\hline \multirow{4}{*}{ Campo Verde } & \multirow{2}{*}{ surface water } & Range / $\left(\mu \mathrm{g} \mathrm{L}^{-1}\right)$ & $0.25-9.3$ & $\mathrm{dt}$ & nd & nd- 0.50 & nd-0.94 & nd & nd & nd & nd \\
\hline & & Mean / $\left(\mu \mathrm{g} \mathrm{L} \mathrm{L}^{-1}\right)(\mathrm{fd} / \%)$ & $0.68(14)$ & (7) & & $0.04(7)$ & $0.07(7)$ & & & & \\
\hline & \multirow{2}{*}{ groundwater } & Range / $\left(\mu \mathrm{g} \mathrm{L}^{-1}\right)$ & nd-18.9 & nd & nd & $0.45-0.561$ & $0.18-0.54$ & nd & $0.23-57.1$ & nd & $0.26-1.48$ \\
\hline & & Mean / $\left(\mu \mathrm{g} \mathrm{L} \mathrm{L}^{-1}\right)(\mathrm{fd} / \%)$ & $0.70(4)$ & & & $0.06(11)$ & $0.03(7)$ & & $2.21(19)$ & & $0.08(11)$ \\
\hline \multirow{4}{*}{$\begin{array}{l}\text { Lucas do } \\
\text { Rio Verde }\end{array}$} & \multirow{2}{*}{ surface water } & Range / $\left(\mu \mathrm{g} \mathrm{L}^{-1}\right)$ & nd-4.92 & nd-1.26 & nd- 0.54 & $0.72-0.82$ & $0.30-0.36$ & nd- 0.46 & nd- 0.29 & nd- 0.54 & $0.02-0.34$ \\
\hline & & Mean / $\left(\mu \mathrm{g} \mathrm{L}{ }^{-1}\right)(\mathrm{fd} / \%)$ & $0.18(11)$ & $0.12(11)$ & $0.01(23)$ & $0.21(23)$ & $0.09(23)$ & $0.08(29)$ & $0.08(31)$ & $0.02(3)$ & $0.07(31)$ \\
\hline & \multirow{2}{*}{ groundwater } & Range / $\left(\mu \mathrm{g} \mathrm{L}^{-1}\right)$ & nd & nd & $\mathrm{dt}$ & $0.28-0.91$ & $0.12-0.39$ & nd & $0.20-0.53$ & nd & $0.02-0.59$ \\
\hline & & Mean / $\left(\mu \mathrm{g} \mathrm{L} \mathrm{L}^{-1}\right)(\mathrm{fd} / \%)$ & & & (3) & $0.20(18)$ & $0.11(22)$ & & $0.06(13)$ & & $0.03(13)$ \\
\hline
\end{tabular}

dt: detected (<LOQ); nd: not detected (<LOD); fd: frequency of detection.
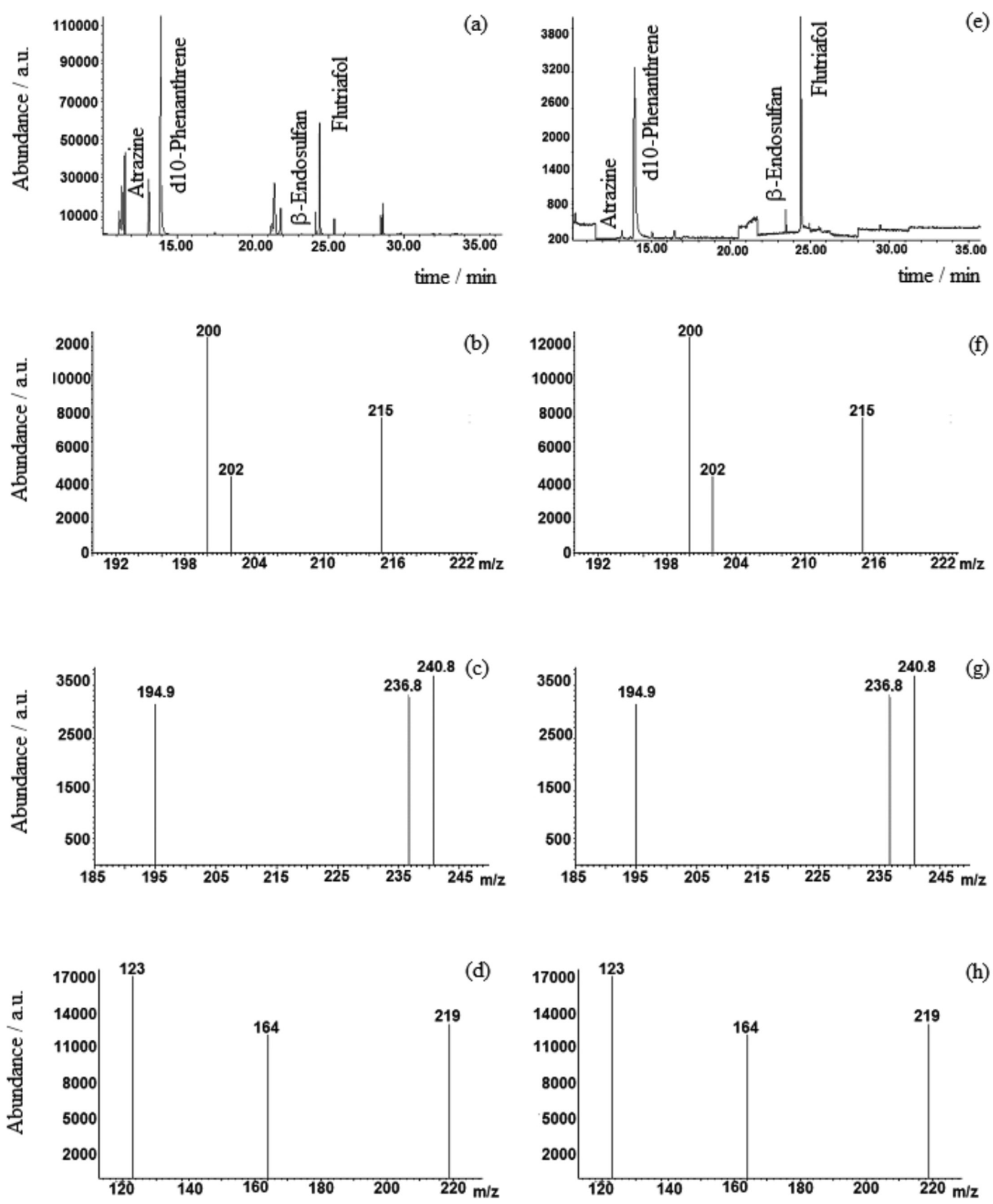

Figure 2. GC-MS chromatograms of: (a) standard solution $(5 \mu \mathrm{g} \mathrm{mL}-1)$, (b) atrazine mass spectrum-standard solution, (c) $\beta$-endosulfan mass spectrumstandard solution, (d) flutriafol mass spectrum-standard solution, (e) sample, (f) strazine mass spectrum-sample, (g) $\beta$-endosulfan mass spectrum-sample and (h) flutriafol mass spectrum-sample. 
In LRV, two degradation products were found in surface water, DEA and endosulfan sulfate. Notably, DEA was detected in the absence of the parental compound at SW1, and its concentration was higher $\left(1.26 \mu \mathrm{g} \mathrm{L}^{-1}\right)$ than that of atrazine $\left(0.20 \mu \mathrm{g} \mathrm{L}^{-1}\right)$ at SW2. Both compounds were detected in similar frequencies, $11 \%$ (Table 5), suggesting that atrazine applications in the area were both recent and non-recent.

Endosulfan sulfate was detected at all the sampling sites except SW18. Throughout the study period, endosulfan sulfate was found in the absence of its parent compound in almost all the samples; this may reflect old applications in the area. When $\alpha$ - and $\beta$-endosulfan and endosulfan sulfate were found simultaneously in the same sample, the endosulfan sulfate concentration was lower than those of the isomers, which may indicate a recent application. Endosulfan sulfate was more frequently detected (29\%) in surface water than $\alpha$-endosulfan $(23 \%)$ and $\beta$-endosulfan (23\%), possibly because it is less absorbed in soil compared to the isomers.

Similarly to the surface water, $\alpha$-endosulfan and $\beta$-endosulfan were found in groundwater samples collected in LRV and CV. These isomers differed from the other compounds in showing the highest $\mathrm{K}_{\mathrm{OC}}$ values and low water solubility (Table 2), which probably result in low rates of leaching. However, for oxisols, the common soil type in the study area, preferential flow is likely to be an important mechanism enabling some pesticides to move down through the soil profile. ${ }^{39}$ In general, oxisols are well drained and have average permeability, favoring leaching, as observed in Primavera do Leste City, Mato Grosso State. ${ }^{40}$ The presence of endosulfan compounds in ground water can be enhanced by their high persistence in the environment. In this study, endosulfan levels were not as high as other compounds analyzed in groundwater samples from CV, but high endosulfan concentrations were found in LRV.

As in surface water, atrazine also exceeded $\left(18.9 \mathrm{~g} \mathrm{~L}^{-1}\right)$ the allowable level established for ground water in Brazil ${ }^{36}$ ( $2 \mu \mathrm{g} \mathrm{L}^{-1}$ ) in samples collected in CV (RGW4, $5 \mathrm{~m}$ well). The sampling point RGW4 is located in the same area where an excessive level of atrazine was also found in surface water (SW57). Both sites (SW57 and RGW4) are in the degraded headwater area of a tributary of the São Lourenço River, with no buffer strips of natural vegetation between the fields and the stream. This area has a high percentage of cropland and crops planted near the stream. In some places, the stream is located at the lower edges of fields, which can facilitate runoff of pesticides, soil and nutrients. A review study concluded that the presence of vegetation such as grass buffer strips along a stream is effective in reducing pesticide runoff and erosion losses. ${ }^{41}$ These results highlight the risk of pesticide contamination in headwaters with no protective plant cover and intensive use of pesticides.

The presence of a vegetated buffer strip along streams and avoiding application in seasons with a high probability of occurrence of runoff events (due to highintensity rainstorms or saturated soils) are some possible measures to mitigate the entry of pesticides into an aquatic ecosystem.$^{42}$ However, these mitigation measures are not usually practiced in the areas studied, as the crops are planted at the beginning of the rainy season, together with intensive application of pesticides, and most of the headwaters have no surrounding vegetation.

Metolachor and flutriafol were also found in samples from CV and LRV. The higher solubility and greater persistence of flutriafol may explain the high levels found in ground water from CV and LRV since this compound is applied in smaller amounts compared to the other pesticides such as metolachlor. Flutriafol was found in wells up to $120 \mathrm{~m}$ deep. Although flutriafol was found at higher levels in groundwater samples from $\mathrm{CV}$ than the other compounds (57.1 $\mu \mathrm{g} \mathrm{L}^{-1}$ in RA-GW3), this pesticide is not subject to Brazilian regulation.

Atrazine, DEA and metolachlor have been previously found in groundwater samples in an area close to CV, Primavera do Leste. ${ }^{17,37}$ The levels reported were lower than those found in the present study, but may indicate non-recent use of these compounds in the area and also a history of pesticide detection in water samples in Mato Grosso State. Pesticides found in surface water and in ground water in this study have also been identified in other locations in Brazil, as compared in Table 6.

\section{Occurrence of pesticides in rain water}

Among the matrices analyzed, more compounds, with higher frequencies of detection, were observed in rain water (Figures 3 and 4). Both regions have high mean air temperatures (monthly means from 22 to $27^{\circ} \mathrm{C}$ ), and soil temperatures can be extremely high in the surface layer (up to $65^{\circ} \mathrm{C}$ ), favoring degradation, but also volatilization. All the compounds found in rain water were also found in surface and ground water, although DIA and methyl parathion were found only in rain water. Similar compounds were also found in rain water samples from CV and LRV, except DIA and chlorpyrifos, which were found only in samples from LRV, and malathion, which was found only in samples from CV.

Higher total pesticide concentrations were observed in February and March, at the end of the wet season (Figures 3 and 4). Intensive rain events that occurred in 
Table 6. Levels of pesticides in surface and ground water in Brazil

\begin{tabular}{|c|c|c|c|c|c|c|}
\hline Pesticides and metabolites & $\begin{array}{l}\text { Analytical } \\
\text { procedure }\end{array}$ & $\begin{array}{l}\text { Water } \\
\text { matrix }\end{array}$ & $\begin{array}{l}\text { Detected / } \\
\text { monitored }\end{array}$ & $\begin{array}{l}\text { Level / } \\
\left(\mu \mathrm{g} \mathrm{L}^{-1}\right)\end{array}$ & Site & Reference \\
\hline 5 Organophosphorus pesticides & SPE; GC/PFPD & surface & $3 / 5$ & $6.700-27.400$ & Alfenas-MG & 1 \\
\hline $\begin{array}{l}13 \text { Organochorines, } 1 \text { chloroacetamide and } \\
4 \text { metabolites }\end{array}$ & LLE; GC/MS-SIM & surface & $16 / 18$ & $0.005-0.390$ & $\begin{array}{l}\text { Itirapina, } \\
\text { Piratininga and } \\
\text { Bauru-SP }\end{array}$ & 2 \\
\hline $\begin{array}{l}1 \text { Carbamate, } 2 \text { imidazolinone, } \\
1 \text { phenylpyrazole, } 1 \text { isoxazolidinone, } \\
1 \text { quinolinecarboxylic acid, } \\
1 \text { triazopyrimidine sulfonamide, } \\
1 \text { triazole and } 1 \text { metabolite }\end{array}$ & SPE; LC/MS/MS & surface & $9 / 9$ & $<$ LOQ-1.400 & $\begin{array}{c}\text { South region } \\
\text { (RS e SC) }\end{array}$ & 3 \\
\hline $\begin{array}{l}1 \text { Benzothiaxinone, } 1 \text { anilide, } 1 \text { clomazone, } \\
1 \text { isoxalidinone, } 1 \text { quinolinecarboxylic acid, } \\
1 \text { alkylchlorophenoxy, } 1 \text { carbamate, } \\
1 \text { imidazolinone and } 1 \text { phenylpuyrazole }\end{array}$ & $\begin{array}{l}\text { SPE; HPLC/DAD, } \\
\text { GC/ECD }\end{array}$ & surface & $5 / 5$ & $0.100-7.000$ & Depressão Central-RS & 4 \\
\hline
\end{tabular}

2 chloroacetamides, 1 dinitroaniline,

4 organochlorines, 5 triazines,

1 chloronitrile, 1 triazole and 3 metabolites

\begin{tabular}{lllllcc}
\hline 8 Organochlorines and 3 metabolites & LLE; GC/ECD & surface & $1 / 13$ & $0.01-0.052$ & Brasília-GO & 11 \\
\hline 7 Carbamates and 3 metabolites & SPE; HPLC/UV & surface & $3 / 10$ & $0.070-2.550$ & Pará de Minas-MG & 12 \\
\hline 2 Organophosphorus, 1 pyrethroid, & SPE; GC/ECD & surface & $6 / 10$ & $0.200-5.660$ & Guaíra-SP
\end{tabular}

1 dinitroaniline, 2 organochlorine,

1 phtalimide, 1 chloronitrile

1 Benzimidazole, 1 carbamate,

1 pyrethroid, 2 organophosphorus

LLE; GC-ECD/FPD surface

$2 / 5$

$7.00-34.00$

Floriano, Nova Guadalupe and

Uruçuí-PI;

Nova Iorque and

Benedito Leite-MA

\begin{tabular}{|c|c|c|c|c|c|c|}
\hline 1 Chloroacetamide and 3 triazines & SPE; CG/MS & surface & $2 / 4$ & $0.030-0.100$ & $\begin{array}{l}\text { Resende and Campos } \\
\text { dos Goytacazes-RJ }\end{array}$ & 15 \\
\hline $\begin{array}{l}1 \text { Benzothiazinone, } 1 \text { isoxazolidinone, } \\
1 \text { anilide, } 1 \text { alkylchlorophenoxy, } \\
1 \text { quinolinecaarboxylic acid, }\end{array}$ & SPE; UV & $\begin{array}{l}\text { surface/ } \\
\text { ground }\end{array}$ & $5 / 5$ & $0.500-2.000$ & Santa Maria-RS & 16 \\
\hline $\begin{array}{l}3 \text { Triazines, } 1 \text { dinittroaniline, } \\
1 \text { chloroacetamide and } 2 \text { metabolites }\end{array}$ & SPE; GC/NPD & $\begin{array}{l}\text { surface/ } \\
\text { ground }\end{array}$ & $7 / 7$ & $<0.023-1.732$ & Primavera do Leste-MT & 17 \\
\hline $\begin{array}{l}2 \text { Triazines, } 1 \text { organophosphorus, } \\
1 \text { isoxazolidinone and 1neonicotinoid }\end{array}$ & $\begin{array}{l}\text { SPE; GC/ECD, } \\
\text { PLC/DAD }\end{array}$ & $\begin{array}{l}\text { surface/ } \\
\text { ground }\end{array}$ & $4 / 5$ & $\begin{array}{l}0.06-15.69 \\
0.08-10.84\end{array}$ & $\begin{array}{l}\text { Agudo, Cristal e } \\
\text { Arvorezinha-RS }\end{array}$ & 18 \\
\hline $\begin{array}{l}3 \text { Carbamates, } 4 \text { neonicotinoids, } \\
1 \text { strobilurin, } 1 \text { benzimidazole, } \\
2 \text { benzoylurea and } 1 \text { phenylurea }\end{array}$ & SPE; HPLC/DAD & ground & $8 / 12$ & $<$ LOQ-68.790 & Primavera do Leste-MT & 22 \\
\hline $\begin{array}{l}1 \text { Triazine, } 3 \text { metabolites, } \\
3 \text { organophosphorus, } 1 \text { organochlorine, } \\
1 \text { triazole and } 1 \text { chloroacetamide }\end{array}$ & SPE; GC/MS-SIM & $\begin{array}{l}\text { surface/ } \\
\text { ground }\end{array}$ & $9 / 11$ & $\begin{array}{c}0.02-9.33 \\
0.18-57.11\end{array}$ & $\begin{array}{l}\text { Campo Verde } \\
\text { and Lucas do } \\
\text { Rio Verde-MT }\end{array}$ & this study \\
\hline
\end{tabular}

aNumber of pesticides detected/monitored; LLE: liquid-liquid extraction; SPE: solid phase extraction; GC: gas chromatography; HPLC: high performance liquid chromatography; UV: ultraviolet detector; ECD: electron capture detector; MS: mass spectrometry; SIM: selected ion monitoring. NPD: nitrogen phosphor detector. DAD: diode array detector; PFPD: pulsed flame photometric detector; FPD: flame photometric detector; SW: surface water; $\mathrm{GW}$ : groundwater; LOQ: limit of quantification.

the beginning of the rainy season may have caused the dilution of pesticides in samples collected from November to January, the period of most intense pesticide application.

Atrazine showed the highest concentrations in the study period. This compound also showed the highest frequency of detection in CV (54\%), followed by $\alpha$ - and $\beta$-endosulfan (46\%) (Table 7). In LRV, the frequency of detection of the compounds that were most often detected followed the order: $\beta$-endosulfan $(82 \%)>$ endosulfan sulfate $(79 \%)>$ metolachlor $(78 \%)>\alpha$-endosulfan $(67 \%)>$ atrazine $(65 \%)$. 

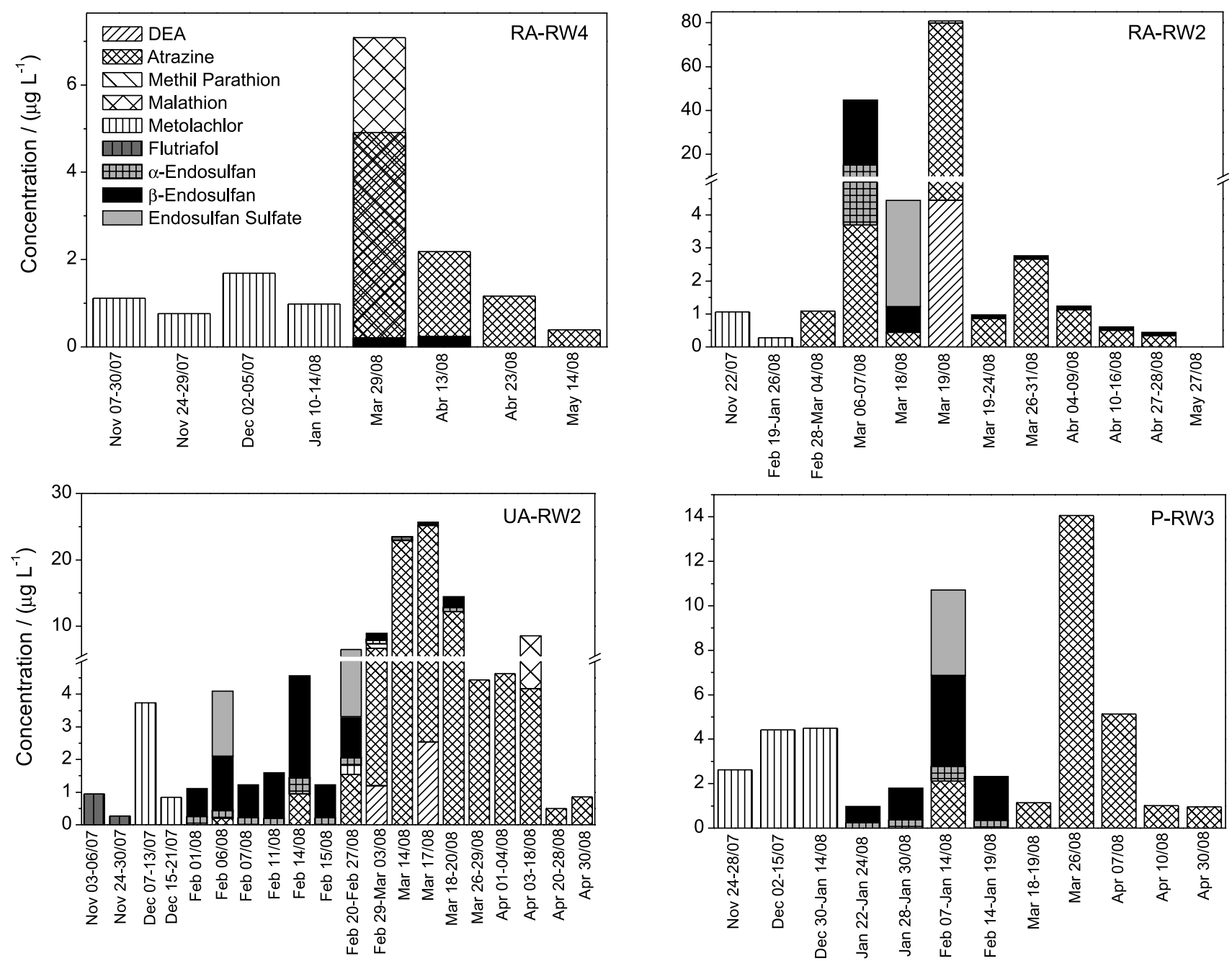

Figure 3. Concentrations of pesticides and metabolites in rain water from Campo Verde sites; UA: urban area-rain water sample site 2, RA: rural area-rain water sampling sites and P: surburban area-rain water sampling site 3 .

A wide range of pesticide concentrations was observed in rain water, from 0.11 to $75.4 \mu \mathrm{g} \mathrm{L} \mathrm{L}^{-1}$ in $\mathrm{CV}$ (Figure 3) and from 0.02 to $47.2 \mu \mathrm{g} \mathrm{L}^{-1}$ in LRV (Figure 4).

Table 7 shows the maximum estimated deposition fluxes (bulk deposition) and frequency of detection for individual pesticides in the study period, for all the sampling sites. Atrazine showed the highest maximum values in both CV (10.8 $\mathrm{mg} \mathrm{m}^{-2}$ ) and in LRV (35.9 $\mathrm{mg} \mathrm{m}^{-2}$ ). The bulk deposition of atrazine was about 5 to 8 times higher than that observed for DEA, the compound with the secondhighest deposition rate in LRV, and about 2 to 5 times higher than the values observed for $\beta$-endosulfan and metolachlor in $\mathrm{CV}$. These findings can be attributed to the larger amounts of atrazine applied (Table 3) and to its ability to undergo long-range transport; atrazine is the most commonly identified pesticide in studies determining pesticides in rain water and bulk deposition. ${ }^{43}$

Interestingly, the maximum precipitation rate for $\beta$-endosulfan was higher than that for $\alpha$-endosulfan in all the sampling sites from CV. In LRV, the difference among the isomer concentrations was not great; however, the frequency of detection for $\beta$-endosulfan was higher (82\%) than for $\alpha$-endosulfan (67\%). Technical grade endosulfan contains approximately $70 \% \alpha$-endosulfan and $30 \% \beta$-endosulfan, and published information regarding the stability of these compounds in the atmosphere is inconsistent. ${ }^{44,45} \beta$-endosulfan was also more frequently detected and at higher concentration than $\alpha$-endosulfan in rain water samples collected in Mato Grosso by Laabs et al..$^{10}$ Measured levels of endosulfan in rain water in the study areas as well as further studies could be useful to monitor the phase-out of endosulfan use in Brazil by 2013.

There was a notable similarity among the sampling sites from rural and urban areas, with respect to the frequency of detection and concentrations of pesticides. Because of the small size of the towns and the proximity of urban areas to farms, the presence of pesticides in rain water calls attention to the possibility of exposure of the population to these 



Figure 4. Concentrations of pesticides and metabolites in rain water from Lucas do Rio Verde sites; UA-RW: urban area-rain water sampling site 1 and RA: rural area-rain water sampling sites.

Table 7. Bulk deposition $\left(\mathrm{mg} \mathrm{m}^{-2}\right)$ observed in Lucas do Rio Verde and Campo Verde

\begin{tabular}{|c|c|c|c|c|c|c|c|c|c|c|}
\hline \multirow{3}{*}{$\begin{array}{l}\text { Pesticide and } \\
\text { metabolite }\end{array}$} & \multicolumn{10}{|c|}{ Maximum bulk deposition / $\left(\mathrm{mg} \mathrm{m}^{-2}\right)$} \\
\hline & \multicolumn{5}{|c|}{ Campo Verde } & \multicolumn{5}{|c|}{ Lucas do Rio Verde } \\
\hline & $\begin{array}{l}\text { Detection / } \\
\%(\mathrm{n}=58)\end{array}$ & RA-RW2 & RA-RW4 & UA-RW2 & P-RW3 & $\begin{array}{l}\text { Detection / } \\
\%(\mathrm{n}=64)\end{array}$ & UA-RW1 & RA-RW2 & RA-RW3 & RA-RW4 \\
\hline Atrazine & 54 & $10.8^{(2-4)}$ & $0.637^{(3-5)}$ & $8.78^{(2-4)}$ & $1.97^{(2-4)}$ & 65 & $11.7^{(11-4)}$ & $30.0^{(11-3)}$ & $20.5^{(12-4)}$ & $35.9^{(11-4)}$ \\
\hline Chlorpyrifos & nd & nd & nd & nd & nd & 27 & $\mathrm{dt}^{(\mathrm{b})}$ & $\mathrm{dt}$ & $\mathrm{dt}$ & $\mathrm{dt}$ \\
\hline DEA & 4 & $\underline{0.577^{(3)}}$ & nd & $0.485^{(3)}$ & nd & 24 & $\underline{0.453}^{(2)}$ & $5.95^{(3)}$ & $3.11^{(12-2)}$ & $4.40^{(2,3)}$ \\
\hline DIA & nd & nd & nd & nd & nd & 3 & nd & nd & $\underline{0.297^{(2)}}$ & ${\underline{0.315^{(2)}}}^{(2)}$ \\
\hline Flutriafol & 7 & $\underline{0.107^{(5)}}$ & nd & $0.419^{(11,3)}$ & nd & 30 & $0.0897^{(11,1)}$ & $0.356^{(11-3)}$ & $0.116^{(12,2)}$ & $0.198^{(11-2)}$ \\
\hline Malathion & 4 & nd & $3.54^{(3)}$ & $\underline{0.782^{(3)}}$ & nd & nd & nd & nd & nd & nd \\
\hline Metolachlor & 26 & $0.367^{(11,2,3)}$ & $0.648^{(11,12)}$ & $1.30^{(12,2,3)}$ & $1.95^{(11-3)}$ & 78 & $1.42^{(11-3)}$ & $1.68^{(11-3)}$ & $1.40^{(12-3)}$ & $0.222^{(11-3)}$ \\
\hline Methyl parathion & 2 & nd & nd & $\underline{0.0921^{(3)}}$ & nd & 3 & $\underline{0.205^{(1)}}$ & nd & nd & $0.0677^{(11)}$ \\
\hline$\alpha$-Endosulfan & 46 & $1.48^{(3-5)}$ & $\mathrm{dt}^{(12)}$ & $0.355^{(2,3)}$ & $0.270^{(1,2)}$ & 67 & $0.916^{(2-4)}$ & $1.46^{(2,3)}$ & $0.722^{(2-4)}$ & $0.883^{(2-4)}$ \\
\hline$\beta$-Endosulfan & 46 & $3.98^{(3-5)}$ & $0.0430^{(3,4)}$ & $1.98^{(2,3)}$ & $1.16^{(1,2)}$ & 82 & $1.04^{(1-4)}$ & $0.822^{(11-3)}$ & $0.506^{(12-4)}$ & $0.350^{(11-3)}$ \\
\hline Endosulfan sulfate & 9 & $0.539^{(3,5)}$ & nd & $0.991^{(2)}$ & $\underline{0.739^{(2)}}$ & 79 & $0.735^{(11-3)}$ & $0.646^{(11-3)}$ & $0.647^{(12-4)}$ & $0.561^{(11-3)}$ \\
\hline
\end{tabular}

Numbers in bracket represents the months which the pesticide was detected in (1 for January and so on); nd: not detected; dt: detected; _. detected in one sample; RA-RW: rural area-rain water sampling sites; UA-RW: urban area-rain water sampling sites; P: surburban area. 
compounds. The presence of pesticides in rain water from a few locations in Mato Grosso (São Vicente, Cuiabá, Jaciara, Rondonópolis, Barão de Melgaço Cities) was reported by Laabs et al., ${ }^{10}$ including atrazine $\left(0.012-0.148 \mu \mathrm{g} \mathrm{L}^{-1}\right)$, $\alpha$-endosulfan (0.004-0.322 $\left.\mu \mathrm{g} \mathrm{L}^{-1}\right)$ and $\beta$-endosulfan (0.004-0.147 $\left.\mu \mathrm{g} \mathrm{L}^{-1}\right)$. Pesticides have also been reported in rain water samples in other countries. ${ }^{27,46-50}$

These results highlight the possible impacts of pesticide deposition on aquatic and terrestrial ecosystems. Considering that pesticides can be dispersed in the atmosphere, the intensive use of pesticides in the study area could affect other remote and important natural ecosystems, such as the Pantanal.

\section{Conclusions}

The distribution of pesticides in surface water, ground water and rain water from urban and agricultural areas of LRV and CV showed similarities among pesticides in both matrices and regions, presumably from non-point agricultural sources. Although a few pesticides, atrazine, metolachlor and endosulfan were the main pollutants in the samples analyzed, other pesticides in current use that are not included in Brazilian legislation were also found in the samples. The findings of sites exceeding Brazilian regulatory limits and the high levels of pesticides in rain water highlight the necessity for further monitoring studies in those regions of Brazil where pesticides are intensively used and no native vegetation protects the rivers. This study revealed the vulnerability of water systems in Mato Grosso State, and calls attention to the risk of pesticide contamination of important headwater streams in this area.

\section{Supplementary Information}

Supplementary information is available free of charge at http://jbcs.sbq.org.br as PDF file.

\section{Acknowledgements}

The authors thank Conselho Nacional de Desenvolvimento Científico e Tecnológico (CNPq) and Coordenação de Aperfeiçoamento de Pessoal de Nível Superior (CAPES-PRODOC) for financial support and Fiocruz and the staff from the sampling sites for their support with the sampling campaign.

\section{References}

1. Santos Neto, A. J.; Siqueira, M. E. P. B.; Quim. Nova 2005, 28, 747.
2. Rissato, S. R.; Galhiane, M. S.; Ximenes, V. F.; Andrade, R. M. B.; Talamoni, J. L. B.; Libanio, M.; Almeida, M. V.; Apon, B. M.; Cavalari, A. A.; Chemosphere 2006, 65, 1949.

3. Silva, D. R. O.; Avila, L. A.; Agostinetto, D.; Magro, T. D.; Oliveira, E.; Zanella, R.; Noldin, J. A.; Ciênc. Rural 2009, 39, 2383.

4. Marchesan, E.; Sartori, G. M. S.; Avila, L. A.; Machado, S. L. O.; Zanella, R.; Primel, E. G.; Macedo, V. R. M.; Marchezan, M. G.; Cienc. Rural 2010, 40, 1053.

5. Azevedo, D. A.; Silva, T. R.; Knoppers, B. A.; Schulz-Bull, D.; J. Braz. Chem. Soc. 2010, 21, 1096.

6. Quinete, N. S.; de Oliveira, E. D. S.; Fernandes, D. R.; Avelar, A. D. S.; Santelli, R. E.; Environ. Pollut. 2011, 159, 3604.

7. Pinheiro, A. D. S.; da Rocha, G. O.; De Andrade, J. B.; Microchem. J. 2011, 99, 303.

8. Filho, C. F. S.; Emídio, E. S.; Dórea, H. S.; J. Braz. Chem. Soc. 2011, 22, 1371.

9. Jacomini, A. E.; De Camargo, P. B.; Avelar, W. E. P.; Bonato, P. S.; Arch. Environ. Contam. Toxicol. 2011, 60, 452.

10. Laabs, V.; Amelung, W.; Pinto, A. A.; Wantzen, M.; Da Silva, C. J.; Zech, W.; J. Environ. Qual. 2002, 31, 1636.

11. Caldas, E. D.; Coelho, R.; Souza, L. C. K. R.; Siba, S. C.; Bull. Environ. Contam. Toxicol. 1999, 62, 199.

12. Parreira, F. V.; Paniago, E. B.; De Carvalho, C. R.; Afonso, R. J. C. F.; Pesticidas: R. Ecotox. Meio Ambiente 2001, 11, 77.

13. Filizola, H. F.; Ferracini, V. L.; Sans, L. M. A.; Gomes, M. A. F.; Ferreira, C. J. A.; Pesq. Agropec. Bras. 2002, 37, 659.

14. Marques, P. R. B. O.; Nunes, G. S.; Queiroz, M. E. R.; Orlanda, J. F. F.; Sousa, H. S.; Santos, T. C. R.; Pesticidas: R. Ecotox. Meio Ambiente 2002, 12, 13.

15. Azevedo, D. A.; Gerchon, E.; Reis, E. O.; J. Braz. Chem. Soc. 2004, 15, 292.

16. Primel, E. G.; Zanella, R.; Kurz, M. H. S.; Gonçalves, F. F.; Machado, S. O. M.; Marchezan, E.; Quim. Nova 2005, 28, 605.

17. Dores, E. F. G. C.; Navickiene, S.; Cunha, M. L. F.; Carbo, L.; Ribeiro, M. L.; De-Lamonica-Freire, E. M.; J. Braz. Chem. Soc. 2006, 17, 866 .

18. Bortoluzzi, E. C.; Rheinheimer, D. S.; Gonçalves, C. S.; Pellegrini, J. B. R.; Maroneze, A. M.; Kurz, M. H. S.; Bacar, N. M.; Zanella, R.; Quim. Nova 2007, 30, 1872.

19. Menezes, J. M.; Prado, R. B.; Da Silva, G. C. J.; Mansur, K. L.; Oliveira, E. S.; Eng. Agríc. 2009, 29, 687.

20. Menezes Filho, A.; dos Santos, P. N.; Pereira, P. A. D.; Microchem. J. 2010, 96, 139.

21. Gomes, M. A. F.; Spadotto, C. A.; Lanchote, V. L.; Pesticidas: R. Ecotox. Meio Ambiente 2001, 11, 65.

22. Carbo, L.; Souza, V.; Dores, E. F. G. C.; Ribeiro, M. L.; J. Braz. Chem. Soc. 2008, 19, 1111.

23. Da Silva, D. R. O.; De Avila, L. A.; Agostinetto, D.; Bundt, A. D. C.; Primel, E. G.; Caldas, S. S.; Quim. Nova 2011, 34, 748. 
24. Caldas, S. S.; Demoliner, A.; Costa, F. P.; D’Oca, M. G. M.; Primel, E. G. ; J. Braz. Chem. Soc. 2010, 21, 642.

25. Prates, C. B.; Gebara, S. S.; Re-Poppi, N.; Quim. Nova 2011, $34,1260$.

26. Agência Nacional de Vigilância Sanitária (ANVISA), Regulamento Técnico para o Ingrediente Ativo Endossulfam em Decorrência da Reavaliação Toxicológica - Resolução RDC No. 28 de 09 de agosto de 2010, Brasil.

27. Hüskes, R.; Levsen, K.; Chemosphere 1997, 35, 3013.

28. Aulagnier, F.; Poissant, L.; Environ. Sci. Technol. 2005, 39, 2960.

29. Mast, M. A.; Foreman, W. T.; Skaates, S. V.; Arch. Environ. Contam. Toxicol. 2007, 52, 294.

30. Motelay-Massei, A.; Harner, T.; Shoeib, M.; Diamond, M.; Stern, G.; Rosenberg, B.; Environ. Sci. Technol. 2005, 39, 5763.

31. Herceg Romanic, R. S.; Krauthacker, B.; Bull. Environ. Contam. Toxicol. 2003, 71, 1034.

32. Jardim, A. N. O.; Caldas, E. D.; Food Control 2012, 25, 607.

33. Whitmore, R. W.; Immerman, F. W.; Camann, D. E.; Bond, A. E.; Lewis, R. G.; Schaum, J. L.; Arch. Environ. Contam. Toxicol. 1994, 26, 47.

34. Agência Nacional de Vigilância Sanitária (ANVISA), Dispõe sobre Os Procedimentos de Controle e de Vigilância da Qualidade da Água para Consumo Humano e seu Padrão de Potabilidade - Portaria MS No. 2914 de 12 de dezembro de 2011, Brasil.

35. Agência Nacional de Vigilância Sanitária (ANVISA), Dispõe sobre A Classificação dos Corpos de Água e Diretrizes Ambientais para o seu Enquadramento, bem como Estabelece as Condições e Padrões de Lançamento de Efluentes, e Dá outras Providências - Resolução No. 357 de 17 de março de 2005, Brasil.

36. Agência Nacional de Vigilância Sanitária (ANVISA), Dispõe sobre A Classificação e Diretrizes Ambientais para o Enquadramento das Águas Subterrâneas e Dá outras Providências - Resolução No. 396 de 03 de abril de 2008, Brasil.
37. Dores, E. F. G. C.; Carbo, L.; Ribeiro, M. L.; De-LamonicaFreire, E. M.; J. Chromatogr. Sci. 2008, 46, 585.

38. Agriculture \& Environment Research Unit, University of Hertfordshire, PPDB: The Pesticide Properties Database, http://sitem.herts.ac.uk/aeru/footprint/en/index.htm accessed in June 2012.

39. Reichenberger, S.; Amelung, W.; Laabs, V.; Pinto, A. A.; Totsche, K. U.; Zech, W.; Geoderma 2002, 110, 63.

40. Dores, E. F. G. C.; De-Lamonica-Freire, E. M.; Quim. Nova 2001, 24, 27.

41. Reichenberger, S.; Bach, M.; Skitschak, A.; Frede, H.; Sci. Total Environ. 2007, 384, 1.

42. Wauchope, R. D. ; J. Environ. Qual. 1978, 7, 459.

43. van Maanen, J. M. S.; De Vaan, M. A. J.; Veldstra, A. W. F.; Hendrix, W. P. A. M.; Environ. Monit. Assess. 2001, 72, 95.

44. Yao, Y.; Tuduri, L.; Harner, T.; Blanchard, P.; Waite, D.; Poissant, L.; Murphy, C.; Belzer, W.; Aulagnier, F.; Li, Y.-F., Sverko, E.; Atmos. Environ. 2006, 40, 4339.

45. Hoff, R. M.; Muir, D. C.; Grift, N. P.; Environ. Sci. Technol. 1992, 26, 266.

46. Bucheli, T. D.; Muller, S. R.; Heberle, S.; Schwarzenbach, R. P.; Environ. Sci. Technol. 1998, 32, 3457.

47. Charizopoulos, E.; Papadopoulou-Morkidou, E.; Environ. Sci. Technol. 1999, 33, 2363.

48. Alegria, H. A.; Shaw, T. J.; Environ. Sci. Technol. 1999, 33, 850.

49. Aulagnier, F.; Poissant, L.; Brunet, D.; Beauvais, C.; Pilote, M.; Deblois, C.; Dassylva, N.; Sci. Total Environ. 2008, 394, 338.

50. Goel, A.; Mcconnell, L. L.; Torrents, A.; J. Agric. Food Chem. 2005, 53, 7915.

Submitted: January 26, 2012

Published online: July 12, 2012

FAPESP has sponsored the publication of this article. 